\title{
Enkens søn fra Nain
}

\author{
Af Kaj Thaning
}

Når man læser Grundtvigs prædikener fra 1834, støder man på en prædiken, der er anderledes end de andre. Det er den om enkens søn fra Nain på 16. søndag efter Trinitatis, som også Christian Thodberg i sin fortale til det års prædikener er faldet over. Han kalder den "ejendommelig personlig", idet Grundtvig hele tiden siger "jeg" (bind 7 s. 46ff.). Thodberg gengiver noget af den: "De, der tidligere hørte ham, vil huske hans optagethed af beretningen om enkens søn og trøsten til den sørgende enke, og at det ikke var fortid, for enken er "...som et Speil for det samme sønderknuste Hjerte til alle Tider, Græde-Kvinden i hvert HjerteKammer, hvor Kiærligheden med de dybere Længsler og de høiere Tanker fik Sæde og Stemme, saaledes stod Moderen for mig og Trøsteren Jesus fra Nazaret, han stod naturligvis ikke for mig blot som en stor Prophet, Gud opreiste i Israel, men som Herren til Gud Faders Ære i Gaar og i Dag og evindelig den samme, som den levende, der seer os og er med sine alle Dage indtil Verdens Ende" (s. 309).

Thodberg minder om Grundtvigs "fantastiske" hukommelse, men mener, at Grundtvig tænker på sin prædiken den 14. september 1823. Jeg tror dog ikke, at det er den, han minder sine tilhørere om. Den er ganske vist stærkt grebet - Thodberg citerer den som et prosadigt - men dels er der tale om en aftensangsprædiken med gammeltestamentlig tekst, dels nævner han ganske vist evangelieteksten til sidst, men kun som en tilføjelse og med meget kort omtale af enkens søn og Jesu ord. Nej, det må dreje sig om en højmesseprædiken, og så er der ikke mange muligheder. De tilhørere, som Grundtvig henvender sig til, må være dem, som har fulgt med ham fra Vor Frelser Kirke, og den prædiken, Thodberg anfører, er altså den tidligste, de har hørt; men den tidligste højmesseprædiken, der kan være tale om, er så den fra 1824 (bind 2, s. 351ff). Den fra 1825 tror jeg ikke på. Derimod er der meget, der taler for den fra 1824. Man kan godt sige, at den handler om "det store Møde mellem Døden og Livet, Sorgen og Trøsten", der stod "lyslevende" for ham, som han siger 
i 1834. Men når han nu prøver at gengive sin gamle prædiken, føjer han til, at man med rette kan spørge ham, "hvorvidt jeg endnu betragter Dagens Evangelium med samme Øine, med samme Haab og Frygt som før".

Vel har han "i de sidste Aar" så idelig og tydeligt besvaret dette spørgsmål, at man ikke kan tvivle derom. "Men ikke desto mindre vil jeg ogsaa idag tale om disse Ting," både fordi det vel kan behøves, og fordi det er det bedste, vi kan gøre, når vi ældes, at bevidne, stadfæste og såvidt muligt udvikle og forklare, "hvad der i Ungdommens Dage til Herrens Ære til vor egen og Menighedens Glæde fremsprang for vort $\varnothing \mathrm{ie}$ og gienlød i vort Inderste".

"Når vi ældes". Grundtvig taler, som om han er blevet gammel. Det er kun ti år siden han holdt den prædiken, som skal sammenlignes med den, han nu holder. Hvad er der sket på vejen fra Vor Frelsers Kirke til Frederikskirken? Det har antagelig nogle af hans tilhørere tænkt over eller spurgt ham om. Det er jo rigtigt, at han i "Nordens Mythologi" har erkendt, at han er indtrådt i alderdommens og eftertankens tid, og i den følgende prædikantperiode kommer det også frem.

I den første prædiken, han holder i 1832, siger han nemlig: "Røsten i Møllen bliver lav", og hans legeme tåler "ikke mer saa tit og saa godt de stærke Rystelser og de mange baade udvortes og indvortes Storme, der er uadskillelige fra Ordets levende, kraftige Forkyndelse i store Krese og Kæmpe-Forhold". Hans "sidste, egentlige Præste-Time er nu indtraadt". Mærkeligt, at Grundtvig efter kun at have levet lidt over halvdelen af sit liv føler sig indtrådt $\mathrm{i}$ alderdommens tid. Forklaringen er dog nok ikke så meget en følelse af legemlig svaghed (og den tids lavere gennemsnitsalder) som den afklaring, han havde lagt bag sig, og som bevirkede, at han nu følte, han var gået over fra manddommens og de stærke følelsers tid til eftertankens rolige tid. Stormene blev nu afløst af klarhed. "Klarere end før nogensinde" ser han nu, "hvorom det giælder og hvorom det ikke giælder" (Menneske først, l. s. 518).

I 1834 hedder det: "Det christelige Liv har nemlig saavel som det naturlige sin Ungdom, da dets Anskuelser udtale og udvikle sig i Kraftens Fylde, med en Friskhed og Fyrighed, som Daarerne kun i ældre Dage stræber at fremkonstle og drømmer aldrig om 
at kunne overbyde, men selvom vor christelige Ungdom var aldeles fri for de Feil, som følge med den naturlige, saa alle vore Anskuelser ei behøve at luttres som Sølvet syv Gange, for at blive rene, christelige Taler, saa trængte dog Menigheden til at høre dem bevidnede og stadfæstede af os i ældre, roligere Dage; thi den samme Skiærsild, som alle høiere Anskuelser af MenneskeLivet i Middelalderen naturlig giennemgaae og som oftest tabe sig i, den samme Skiærsild prøver ogsaa vore christelige Anskuelser ...".

Grundtvig havde altså lært at skelne mellem det kristelige og det naturlige liv -hvad der er noget nyt i en prædiken - og han vidste nu, at hans kristelige liv kunne have været fuldt af fejl såvel som hans naturlige liv. Derfor måtte der en skærsild til $i$ begge henseender. Den kom han igennem, og måtte nu stå til regnskab for resultatet. Man kan tilføje, at den skærsild, han måtte igennem, lyser gennem den dynge af manuskripter, der førte op til indledningen til "Nordens Mythologi", hvor han blandt andet tumlede med forholdet mellem det kristelige og det naturlige liv. Og de anfægtelser, som han taler om i udkastene til indledningen til "Haandbog i Verdens-Historien" viser, at Grundtvig har været igennem svære Fristelser, som Prædikerens bog har stillet ham overfor: Er der overhovedet noget, der betyder noget? Men det gik ham altså ikke sådan, som det kunne være gået, at hans "høiere Anskuelse" tabte sig i skærsilden; den kom han igennem. Han forandrede sit livssyn (Menneske først s. 306ff).

Det kan man ane gennem denne prædiken. Men han fortegner opbruddet fra sit gamle kristendomssyn, for så vidt som han husker sin tidligere prædiken som anderledes, end den var.

Trods tilbageblikket i 1834 er der ikke tale om, at han i 1824 har sammenblandet det kristelige og det naturlige liv - uden for så vidt som han ikke tænkte på nogen adskillelse som nu. Det vil altså sige, at han nok tænker på hele baggrunden for sin kristne forkyndelse. Der er nemlig tale om en udpræget sammenblanding af kristendom og danskhed i f.eks. det store digt "Nyaars-Morgen", som netop er udsprunget af et begejstret helhedssyn. Udgangspunktet er en vision i den store brevveksling mellem Nørrejylland og Christianshavn, hvor en fornyet Steffens-inspiration har fremkaldt et enhedssyn af kristendom og videnskab. Det medfører, at Grundtvig på ny måde bliver grebet af billedsproget, hvad der 
kan ses af hans prædiken på 2. påskedag, som bl.a. er trykt i Toldbergs disputats som et vigtigt aktstykke om Grundtvigs forhold til poesien. Men antagelig som følge af den nye digteriske inspiration påbegynder Grundtvig sit store digt.

Det bæres netop af en kristen-dansk vision. Den stærke stemning præger da også de samtidige prædikener. I en af dem siger Grundtvig ligefrem: "Kan I ikke mærke, at det er blevet bedre med mig paa det sidste?" Hans overbevisning får stærke subjektive udtryk. Det er, som om han vil presse sig ind på sine tilhørere. I 1834 ved han, at han er blevet en anden.

I et udkast til "Nordens Mythologi" siger han bl.a.: selv om han stadig ønsker sig "velvillige og skiønsomme Læsere", er han dog "blevet meget ligegyldigere ved mine Læeres Mening og Dom, end jeg før har været, thi hvad Læsere efter min Bog dømmer om mit Hjertelag, min Tro og Tænkemaade, som før har brudt mig meget, lader jeg staae ved sit Værd, og tænker kun paa at vinde Læseren for Bogen med hvad deri virkelig indeholdes, som jo hverken kan være Tro eller Hjerter, men kun Tanker og Anskuelser, Kundskab og Oplysning." Han mener, at det nok kommer af, at han er blevet lidt "koldsindigere", antagelig af den engelske luft. Der kan nordiske naturer, uden at vide hvordan, lære at kende, "i hvad Forhold Aand og Legeme, Liv og Død, Haand og Mund, Ord og Pen, og alle menneskelige Ting virkelig staae til hinanden" (Menneske først s. 286f).

I prædikenen i 1834 er der ganske vist ikke tale om "Tro og Hjerter", men også i den henseende har Grundtvig forandret sig. Han vil ikke længere trænge ind på nogen, som han føler, han før har gjort det. Meget tilspidset siger han i et overstreget afsnit af trykmanuskriptet til "Nordens Mythologi", at troen er "en fri Sag", som man ikke skal pånøde andre. "Troen er en egen Sag, og ret egentlig hvert enkelt Menneskes egen Sag, og vel maae det være mig særdeles kiært, om I vil dele min christelige Tro, men det er kun, fordi jeg skal elske min Næste som mig selv, thi ellers kunde det være mig ganske ligegyldigt, hvor Mange eller hvor Faae der havde den Tro, der sikrer mig det evige Liv. derfor hvis nogen af jer har Lyst til at vide, hvordan min Troes Sikkerhed paa det evige Liv udtaler sig, de maae enten spørge mig derom eller høre efter, naar jeg ved given Leilighed taler derom, thi naar jeg taler eller skriver som Borger, som Skjald eller Vidskabsmand, da er det 
ikke Tid eller Sted enten til at præke eller skrifte, saa naar jeg før har gjort det, var det en Feiltagelse, der kun lader sig undskylde med det alt for gamle Vilde-Rede $\mathrm{i}$ vore Kirkelige og Borgerlige og Videnskabelige Forhold..." (Menneske først s. 259ff).

Hvordan end Grundtvig her fik udtrykt sig, så er det $\mathrm{i}$ hvert fald noget nyt, han her får sagt. Det kunde han ikke sige før 1832. Denne nye erkendelse ligger nok også bag den adskillelse, han taler om i prædikenen 1834, hvor han siger, at han sammenblandede det kristelige liv med "vort naturlige Folkeliv". Det er åbenbart her, han taler som borger, som skjald og som videnskabsmand. Her har han ikke før kunnet skelne. Det medførte, at hans kristelige anskuelse kunne mistydes og betvivles. $\mathrm{Nu}$ har den imidlertid været igennem skærsilden, og den har ikke tabt det mindste af sin højhed til Herrens pris eller af sin trøstelighed til menighedens glæde, "men kun sin Urimelighed og Dunkelhed der ikke kom fra Herren men fra mig selv".

Og senere hedder det: "Anskuelsen fordunkles ikke mere af sin Danskhed, thi vel miskiender jeg ingenlunde det særdeles venlige Forhold, der giennem Aarhundreder fandt Sted mellem Christi Tro og Folkelivet herinde og opgiver heller ingenlunde mit Haab, at Christenhedens Gienfødelse her ret aabenbar vil vise sig ogsaa for Verden som en god Gierning, men det er dog kun en Drøm, og Propheten vil ingenlunde fortælle os saadanne Drømme, men han byder os at skille dem skarpt fra Guds Ord som Halmen fra Kornet.,..".

Det er mærkeligt, at Grundtvig så stærkt betoner adskillelsen mellem kristen tro og danskhed. Det kan ikke være nogen polemik mod hans prædikener fra 1824. Der kan kun være tale om en reaktion mod grtundsynet $i$ "Nyaars-Morgen" og dens vision af kristendom og danskhed $i$ eet (jfr. at Bent Christensen i sin licentiatafhandling kalder digtet "en drøm"). Men Grundtvig kan også tænke på sit "Literaire Testamente", hvor sammenblandingen kommer stærkt frem (1827). Her spørger han sådan: "Skaber da ikke Bibelens, Historiens og Nordens Aander, som jeg skiftevis tjener og forvirret sammenblander, skaber ikke de ... et grueligt Chaos, for hvilket man i det Mindste maa advare den boglærde Ungdom, der kunde lade sig overvælde af Kraften, henrive af Dristigheden, nedlokke i det dunkle Dyb, paa hvis Rand man svimler, og i hvis Svælg man forgaaer!" (US V s. 174). 
Her er der ikke tale om den adskillelse mellem halm og korn, danskhed og kristendom, som han taler om i prædikenen. Den, han taler om i slutningen af tyverne, er adskillelsen mellem "Kirke og Kirke-Skole, Christendom og Theologi, Bibelens Aand og Bibelens Bogstav" (US V s. 178). Men her ligger hans rent kirkelige Opdagelse bag (1825f), ikke den senere mellem kristeligt liv og folkeliv. Ellers taler han om sin "Gjæring, som I kan see ... jeg har ladet saa varm, saa fuldstændig og levende, som jeg det kunde, udstrømme paa Papiret" (s. 174). Og senere: "See, derfor fordi Kampen mellem Aser og Jetter, med Valhal og Gimle, var for Skjalden Eet med den, han fandt og førde i sit Inderste, og saae i Bibelen forklaret, see derfor kom der ingen Grund-Strid $i$ hans Syn og Skrift, han gik ei fra Bibelens Aand, da han fulgde Nordens, og den gamle Kæmpe-Aand forlod ham ingenlunde, da han udelukkende vilde oplives og styres af den store Aand, som skabde Nyt paa Jorden; thi Aander, som kan enes, udelukke ei hinanden, i Aandens Rige er Høvdingen ei blot over Alle, men Alle er i Ham, og Han er Alt i Alt." (S. 176). I parentes bemærket nærmer han sig her de ord, hvormed han plejer at karakterisere panteismen. - Så fortsætter han med at identificere menneskehistoriens ånd med Bibelens ånd: "her er Forklaringen over mit Chaos".

Det er dette kaos, som opløses for ham og bl.a. giver afklaringen i prædikenen fra 1834, efter at han er indtrådt i alderdommens og eftertankens tid. Det er ejendommeligt, at Grundtvig i 1827 derimod føler sig "i Livets Middel-Alder". Efter at have erklæret, at han nu står med klarhed til at fortsætte og fuldføre den bane, han er inde på, siger han: "See, det var mit Ønske i Ungdoms-Dagene, at kunne i Livets Middel-Alder staae saaledes med klaret Blik over mig selv og Menneske-Banen, uden at have tabt min Lyst til Idealerne, som vinkede ... uden at begræde Aarene, som randt..." (s. 175).

Igen en parentes: det er uhyre sjældent, at Grundtvig bruger ordet "idealer". Men det skyldes måske her, at han igen har stiftet bekendtskab med "de store Tyskere", som han kalder sin ungdoms læremestre.

Året efter det "Literaire Testamente" udgiver han anden del af "Søndags-Bogen", det bind, hvor den eneste prædiken om enkens søn forekommer i dette værk. Det er den sidste i 2. del (1828), 
og den er en udarbejdelse af prædikenen fra 16. s. efter Trinitatis 1824, og som i flere andre tilfælde er Søndagsbogens bearbejdelse svagere i stemningen end forlægget. På eet punkt er der en forbindelse med den første af Fredrikskirkeprædikenerne fra 16.s.e.trin., den i 1832. (udtrykket "Græde-Kvinden"). Den i 1833 mangler, og så kommer den, jeg har hæftet mig ved, den fra 1834. Men skellet går ved 1832, og Søndagsbogen hører altså med til hans "Middelalder".

Det, der i modsætning til 1834-prædikenen karakteriserer den fra 1824, er dens tale om "Haabet": hvem er menneske, hvem har et hjerte, som slår for mere end øjeblikkets lyst, som føler sit slægtskab med Gud i det evige livs vidunderlige længsel, "hvem kender ei denne Moders Eenbaarne, hvem veed det ikke, at hans Navn er Haabet, det evige Livs Haab ... Naar Hjertet seer sit Haab paa Gravens Rand, hvor er da for det Trøst at finde uden i en Guddoms-Røst, som toner: græd ikke!" Grundtvig anfører sit yndlingsskriftsted i denne tid, Johs.3,16, og tilføjer så, at når "dette Livets Ord" lyder, "er det ikke da, når vi føler, at Gud har besøgt sit Folk ... det uforkrænkelige Haab ... det er en stor Prophet $i$ hvem Gud besøger og trøster sit Folk, ja, det christelige Haab Christus i os, det er Propheten ... og er selv ... det levende Pant paa den Herlighed, som skal aabenbares" (bind 2 s. 353f).

Grundtvig er i sommeren 1824 i glad stemning, jfr. "NyaardMorgen", og siger, at håbet, der var dødt, er "igien lyslevende opstaaet" og taler til menigheden med levende røst. "Det er saa vist, som at vi selv er til, saa vist som vort Hjerte i denne Time sødt bevæges af det evige Livs uforkrænkelige Haab i Christus Jesus, vor Herre" (s. 356).

Søndagsbogens udgave af denne prædiken følger den i hovedtrækkene: Græd ikke! dit håb skal opstå (s. 486). Med de ord bevægedes folket altid sødt, "naar det ei blot oplæstes som gammel Skrift, men udlagdes som et ufravigeligt og levende Guds Ord, hvoraf Opstandelsens og det evige Livs frydefulde Haab udsprang ..." (dette er nyt og skyldes 1825f). Uden at begrunde det nærmere siger han: "Vi høre Rygter derom fra alle Kanter i Christenheden, og vi føle det jo selv ... at Haabets den store Prophet er igien opvakt ... Dog ... vi tvivle nogen Gang endnu, og Haabet er ei sjelden svagest netop hos os, paa hvem Herren gjorde et Tegn til det gode ... og det kommer ... af Haabets 
underlige Levnedsløb og Skiæbne paa Jorden". - Den tone af tvivl forekommer ikke i 1824.

Lidt senere (s. 492): "Naar vort forstummede, døde og magtesløse Haab om den store Opvækkelse i Menigheden kommer igien til Liv og til Orde, da maa vi vel vogte os for det æventyrlige: vi kan ikke skabe det Folk, som skal love Herren, og vi skal ikke falde i Mishaab, om vi end en Stund forgiæves lytte efter Ordet, som skal forkynde Livets Seier over Døden" (hos dagens konfirmander). "Men Jesus Christus er vort Haab ... og med dette Haab vil vi trøste hverandre ...". Mod slutningen taler Grundtvig om "det dyrebare Haab, hvis Prøvetid er ei fuldendt, før Herren kommer øiensynlig som han drog herfra" (s. 494). At bodskristendommen endnu ikke er overvundet, vidner slutningen om: "Hvilken Vei skulde dog vel være for lang, hvilken Sti for tornet til Himmeriges Herlighed, hvilken Død skulde være for haard en Overgang til det evige Liv!" Og det sidste afsnit begynder: "Saa staae da, under Tidens Løb, det store Haab, som Ordet skaber, og han selv ved Maalet, for vore Øine, som den store Kvindes Søn af Nain." Og slutordene understreger endnu en gang håbet: "Amen" $i$ hans Navn, som er Haabet, Herlighedens Haab i os, ved den Hellig-Aand! Amen!"

Det er en mærkelig overgang at komme fra denne prædiken til den næste om enkens søn - den i 1832, hvor ordet håb ganske vist nævnes et par gange, men uden at det har den centrale stilling i prædikenen som i 1824 og 1828 . Kristus kaldes ikke mere "Haabet". Troen er blevet nutidig: ... "kun i Ordet har vi ham, Ordet var Livs-Tegnet, da vi opvaktes fra de Døde, og forstummede vi da var det Døds-Tegnet." "Spaadommen tier, naar den er opfyldt, og Ophøret var aldrig klarere end nu".

"Derfor, da Herren har besøgt os og opladt vor Mund, saa vil vi tale om ham alle Dage, visse derpaa, at det er ligesaa nødvendigt og ligesaa fornøieligt som at drage Aande, hvad jo dog kun Faa blive kiede eller trætte af at giøre hvert Øieblik, thi i Troens Ord om Herren deri aander han paa os og siger: annammer den Hellig-Aand og deraf drager vi vor Aande til at leve med ham som han lever med Faderen glædelig, salig evindelig Amen!"

Troen er blevet nutidig og har ikke mere sit tyngdepunkt $i$ ord som længsel og håb. De kristnes lovsang stiger nu hver morgen til Himlen. I det væsentlige er "den græske vækkelse" foregrebet, og 
den har f.eks. ikke afsat sig på 16. s.e.trin. 1837. Den store drejning sker i 1832. Thodberg siger da også (bind $10 \mathrm{~s} .27$ ), at langfredagsprædikenen 1837 "minder om fasteprædikenerne i 1832."

At Grundtvig er på nye veje, fremgår også af et sted i 1832prædikenen: "... i ham finde vi hele den menneskelige Natur i sin Reenhed og forenet med hvad der tilfredsstiller, adler og saligg $\varnothing r$ den, forenet med den guddommelige Natur hvori Menneske-Hjertet nødvendig maae sukke om Deelagtighed, fordi den haver alene Udødelighed ...". Prædikenen kan sammenfattes i dette: "Kun i Ordet har vi ham, Ordet er Livs-Tegnet da vi opvaktes fra de Døde".

For såvidt peger den og andre prtædikener $\mathrm{i}$ trediverne frem mod salmen "Herren han har besøgt sit Folk" (SV I nr. 232). Her er evangeliet også blevet til nutid: natten er blevet til morgen, sorgen er slukket. Som før sammenlignes kirken med den sørgende enke, der glemte, at han "i Gravens Land/ Stormede Dødens Taarne". Hun græder sig blind under korset (jfr. bodskristendommen). Derfor lå frelseren i sorten jord nætter såvel som dage. Men nu er livets ord stået op af døde og skal ikke mer smage døden. Men kirkens bitre sorg kom netop af, at ordet lå i dødens bånd - det kendtes kun som nedskrevet: "Ja, vor Herre syndes død ... Som et Liig paa Baare" (stroferne er jo meget længere i Sang-Værk I end i salmebogen). Men Herren er dog sine tro - trøsteren var med kraft til stede, ja Helligånden sankede gloende kul på vort hoved, vakte det døde op og sagde: "Evig ung stat op igjen, Himlens Morgen-Røde!". "Levende blev i samme Stund ... Ordet fra Herrens egen Mund, Laae ikke meer i Dvale! Det er et Vidunder stort, Større end det ved Nains Port ..."

Konklusionen kommer med det "nu", der præger gennembruddet i 1832: "Sjunger da nu i høien Sky: Ordet stod op af Døde ... $\mathrm{Nu}$ med Ordet er os nær Herren over Himlens Hær" og "Lever nu op, I Christne smaa! Nu er her godt at være". Opgøret med den overleverede kristendom udvides til sidst med den ødelæggende undervisning i skolen: "Ei med Ferle, ei med Riis, Lære Børn vi Herrens Priis, Men med Paaske-Sange ..."

Den unge mand på båren er blevet sammenlignet med den døde kristendom, som Grundtvig nu gør op med, i alle dens former. Han har tidligt været klar over dens virkninger. I 
påskeprædikenen 1830 beskriver han tilstanden $\mathrm{i}$ de lutherske fædres dage, "da al vor Christendom udledtes af Skriftklogskab og henførdes til en fortvivlet Sjæls Gru under Sinai og Trøst under Korset, saa det var kun afdøde fra Verden og de Døende paa Sotte-Sengen, der følde sig levende tiltalte deraf, medens det faldt tungt og dødt ... paa Børnenes, paa Kvindernes, paa den uerfarne Ungdoms og dermed paa Mængdens Hjerter ..." (SB III s. 263).

Grundtvig taler, som om han var brudt igennem til sit nye syn. Opdagelsen af 1825 har da også været en kolossal befrielse for ham - fra den gamle bogstavdyrkelse, som prægede hele hans tid. Der er noget stærkt profetisk over prædikenen, og ganske vist bruger han mod sædvane ordet "nu", men nærmest i betydningen: nu kommer det. Ikke i betydningen: nu er det sket.

Han taler om "det levende, sikre, mundtlige, lydelige Ord" i modsætning til "det døde, uvisse, skrevne, stumme Tegn i Bogen". Men der er endnu ikke tale om "Ordet af Vorherres Mund" som meget senere. Først det giver ham den ro og tillid, der făr ham til at prædike på baggrund af, at det er sket, at ordet er stået op af døde. Man kan så spørge, hvad der har givet ham denne overbevisning. Jeg mener selv, at den er kommet samtidig med, at livet gennem Englandsrejserne blev virkeligt og nutidigt for ham. Dermed blev kristendommen også virkelig og nutidig. "Af Herrens egen Mund" blev udtryk for denne nutidighed. Opdagelsen af 1825 stod parat til at skænke ham et udtryk for den tiltale til ham, som han skulle leve af. Det er ham ikke længere nok at tale om "den hele Menigheds levende, høitidelige Vidnesbyrd ved Daaben, om den Tro, vi skal alle dele og bekiende" som langt sikrere end hvad der står i alverdens bøger (s. 265). - Grundtvig var i 1830 ikke parat til at synge "Herren han har besøgt sit Folk", selv om han varsler om sin kommende salmesang: "hvor skal vi finde paa Ord til en Psalme, ja til tusinde Psalmer og aandelige Viser" (s. 271). Resten af Søndagsbogen rummer ikke nær den afklaring, som påskeprædikenen (der er skrevet på selve påskedag) trods alt rummer. Han har ikke kunnet holde sig på højderne.

Men for nu at vende tilbage til prædikenen fra 1834, møder man det samme som så tit hos Grundtvig, at han understreger kontinuiteten i sin forkyndelse. For selve evangeliet står i samme glans for ham som før: enken og hendes $\$ \varnothing n$, som vaktes til live. Han har altid i den sørgende enke set et udtryk for kirken. Den 
første gang kommer det $\mathrm{i}$ en tilføjelse til prædikenen på 16.s.e.trin. i året 1821 (Præstøprædikener bind 1 s. 296). Den ender met et stikord: "Christi Kirke nu som Enken af Nain". Den tanke har han nok udfoldet og sluttet sin prædiken med.

Alligevel polemiserer prædikenen i 1834 altså mod hans tidligere syn. Men i virkeligheden rammer hans kritik ikke selve prædikenerne, men den baggrund, på hvilken de er holdt, sammenblandingen af det kristne og det naturlige liv, som han nu har brudt med. Han har adskilt halmen fra kornet. Men hvad han bedst husker er selve den stemning, der har båret ham, og som selvfølgelig har præget hans forkyndelse i hans ungdom (der åbenbart har omfattet årene $\mathrm{i}$ Vor Frelsers kirke). Da udtalte hans anskuelser sig i "Kraftens Fylde" og med en "Friskhed og Fyrighed", som han nu "i ældre, rolige Dage" ikke kan overbyde.Han erkender også, at der klæber "noget æeventyrligt" ved vore "Ungdoms-Anskuelser", den samme "Fyrighed og Friskhed", der giver disse anskuelser den "Kraft og Glands", der udmærker dem. Det samme giver dem også "den forvovne Dristighed og mangefarvede Dunkelhed, der ved rolig Eftertanke skader deres Virkning og frister til Tvivl om deres Ægthed".

Men nu er han gået gennem skærsilden. Hans anskuelse tabte dog ikke sin højhed til Herrens ære eller sin trøstelighed til menighedens glæde, "men kun sin Urimelighed og sin Dunkelhed der ikke kom fra Herren, men fra mig selv" (S. 312).

Den samme skærsild ligger bag, når han $i$ et udkast til en prædiken 4. marts 1832 taler om sine "fyrigste Dage" og siger: "... sandelig, dette har været den store Feil iblandt os, at vi nøjedes med et dunkelt og ubestemt Begreb baade om Aand og Sandhed, thi derfor var vi saa tvivlraadige og mistrøstige ... derfor toge vi saa ofte Bogstaven for Aanden, eller Sværmeriets og Vildfarelsens Aand for Guds, derfor bare vi for det meste Dødens Frugt istedenfor Livets, derfor fik vi det onde Ord paa os blandt Hedningerne, at vi vidste ikke selv hvad vi meende med Troen og Aanden, vi førde i Munden, saa vor Christendom var enten et tomt Mundsveir, en død og ufrugtbar Tale om allehaande underlige Ting, eller den var en vild og mørk, stormende og brusende Heftighed, hvormed vi stræbde at paatvinge alle Mennesker vor Tro og Tankegang, vor Maade at see og føle, leve 
og handle paa, der maaske kunde være god nok for os, men ikke for alle".

Trods al vor gode vilje "talte vi og vore Fædre tit saa dødt og koldt eller saa dunkelt og indviklet om disse Ting, og stillede vor Sag saa bagvendt, saa ubesindig, og tilsyneladende saa ukiærlig, at vi gav overflødig Anledning til Bagtalelse af det gode Navn, vi bære, og til Miskiendelse af den gode Vilje og Hensigt, vi var os bevidste." (Bind 5, s. 79f).

Det selvopgør, som dette prædikenudkast (fra 4/3 1832) og prædikenen 16.s.e.trin. (1834) giver udtryk for, er grund nok til at pege på året 1832 som et gennembrudsår, uanset hvor mange optræk dertil der har været $\mathrm{i}$ de foregående år. Vi læsere ville ikke have kunnet markere forskellen på før og nu med stærkere udtryk end hans egne. Ingen af os ville have karakteriseret hans tidligere forkyndelse så voldsomt som han selv. Han må virkelig være blevet et andet menneske.

- Til slut kan nævnes, at enkens søn forekommer i en helt anden sammenhæng end prædikenens, nemlig i den artikel om folkelighed og kristendom, som Grundtvig skrev i anledning af et anonymt indlæg i Berlingske Tidende (1847). Han er blevet beskyldt for at have sammenblandet nordiskhed og kristendom, hvad han benægter. Men han indrømmer, at han nok $\mathrm{i}$ sin ungdom har nævnt danskhed og kristendom så tit $\mathrm{i}$ eet åndedræt og i en så dunkel forbindelse, "at man let kunde tænke, jeg paa en eller anden Maade sammenblandede dem" (US IX s. 81). Erkendelsen heraf minder om prædikenen i 1834. Men nu vil han stræbe at oplyse "et Forhold, der ikke blot har været dunkelt for mig, men er det endnu over hele Christenheden, det rette Forhold nemlig mellem Folkelighed og Christendom". (Sst.) - Ifølge prædikenen 1834 synes han at have indbefattet tiden op til ca. 1830 i sin ungdom.

Han går hårdt imod det forbehold, man tit møder, at "Danskheden naturligviis maa christnes før den er værd at nævne", så han "stræber stedse tydeligere at holde Danskhed og Christendom ud fra hinanden, vist nok ingenlunde som uforligelige, men dog som saa høist forskiellige, at den ene kun giælder i en Krog af Norden, den anden over hele Verden, den ene giælder kun for en Tid, den anden baade for Tid og Evighed." (Sst.) 
Grundtvig er nået frem til det syn, at levende folkelighed må være en forudsætning for levende kristendom. Det var omvendt i hans ungdom. Da drømte han om, "at man kunde og skulde først blive en levende Christen og saa tillige en Dannemand" (Sst. s. 87). Men han ser nu, at den danske folkeligheds død er folkets åndelige død, der må helbredes ved folkelighedens oprejsning, før end der kan tales til og med folket om "levende Christelighed" (sst.) - andet er det ikke, han nu påstår, og anderledes har han "ikke i mange Aar" sammenblandet danskhed og kristendom.

I den anledning taler han så om enkens søn: "... hvad der af Danskheden endnu er ilive, ligner paa et Haar den trøstesløse Enke ved Nains Port, som følger sin eenbaarne Søn til Graven." (S. 86f).

Under disse omstændigheder at ville tale til det danske folk om levende kristendom er naturligvis unyttigt. Der skal ikke tales til den døde ungersvend om "Veien til det evige Liv", men der skal siges et "Stat op!" - og det vil åbenbart sige: bliv et levende menneske! - "thi hvor enten det timelige Liv fattes eller er under dyb Hjertesorg kun til Byrde, der er Talen om det evige Liv, naar den ikke bliver til Spot, dog nødvendig til Unytte." (Sst. s. 87).

- Man må være den anonyme indsender i Berlingske Tidende taknemmelig, fordi Grundtvig derved fik lejlighed til at få sine begreber klaret: man får indtryk af, hvad han mener med at sige "folkelighed først", som en udvidelse af hans "Menneske først" (1837). Han er kommet videre de sidste 10 år.

Men grunden blev lagt med hans adskillelse af det kristelige og det naturlige liv i begyndelsen af tredverne. Prædikenen i 1834 er en vigtig statusopgørelse. 
Forkortelser:

US $=$ N.F.S. Grundtvigs Udvalgte Skrifter ved Holger Begtrupp, I-X, 1904ff.

$\mathrm{SB}=$ Christelige Prædikener eller Søndags-Bog af Nik.Fred.Sev. Grundtvig I-III, 2. udg. 1859-60. 1. udgave udkom 182722-31.

Grundtvigs prædikener er iøvrigt citeret efter Christian Thodbergs udgave af Grundtvigs prædikenmanuskripter bind I-X. 